\title{
The Effect of IFRS Adoption on Investment Management: A Review of the Literature
}

\author{
Konstantinos Kapellas, Georgia Siougle* \\ Department of Accounting and Finance, School of Business, Athens University of Economics and Business, Athens, Greece \\ Email: kkapellas@aueb.gr, ${ }^{*}$ gsiougle@aueb.gr
}

How to cite this paper: Kapellas, K. and Siougle, G. (2018) The Effect of IFRS Adoption on Investment Management: A Review of the Literature. Technology and Investment, 9, 1-23. https://doi.org/10.4236/ti.2018.91001

Received: November 20, 2017

Accepted: January 23, 2018

Published: January 26, 2018

Copyright $\odot 2018$ by authors and Scientific Research Publishing Inc. This work is licensed under the Creative Commons Attribution International License (CC BY 4.0).

http://creativecommons.org/licenses/by/4.0/

(c) (i) Open Access

\begin{abstract}
Recent literature contains a number of studies that provide evidence that improvements in the performance related to business investments are associated with the main positive results of the implementation of international financial reporting standards (hear after IFRS). This study is an effort trying to summarize empirical evidences in current literature about the effect of the IFRS adoption on investment management. We summarize literature on the effect of IFRS a) in a European setting b) in a worldwide setting. We especially refer to the effect of European Crisis on Investment Management. We summarize evidence on the impact of IFRS adoption worldwide on investments assets, foreign direct investments (FDIs), cross boarder investments (Merger and Acquisition activities) and foreign mutual fund ownership. We finally present some evidence on the impact of IFRS adoption on US home bias and try to document the impact of IFRS adoption on international listing and IPOS in global markets.
\end{abstract}

\section{Keywords}

International Financial Reporting Standards (IFRS), Investment Management, European Crisis

\section{Introduction}

Financial economics theories, when they focus on the area of investment efficiency, argue that the information asymmetry between firms and outside capital providers is one of the major drivers of suboptimal capital investment. As already known by academic literature, an important goal of financial accounting information is the reduction of adverse selection costs or moral hazard issues related to information asymmetries in order to enhance capital markets efficiency. The reduction of information asymmetry is argued that could be 
achieved by adopting a single set of global standards, which improves the level of comparability of financial statements, and as a result the ability of investors in identifying profitable investment opportunities. Recent literature contains a number of studies suggesting that improvements in the performance related to business investments are associated with the main positive results of implementing international financial reporting standards (hear after IFRS).

Our study is an effort trying to summarize empirical evidences in current literature about the effect of the IFRS adoption on investment management. The evidence are presented by subject and then by chronological order. We summarize literature on the effect of IFRS in a European setting. We specially refer to the effect of European Crisis on Investment Management. Then we summarize research papers examining the impact of IFRS adoption in investment management worldwide. We present evidence on the impact of IFRS adoption worldwide on investments assets, foreign direct investments (FDIs), cross boarder investments (Merger and Acquisition activities) and foreign mutual fund ownership. We further present some evidence on the impact of IFRS adoption on US home bias. We finally document the impact of IFRS adoption on international listing and IPOS in global markets. The rest of the paper is organized as follows: Section 2 presents evidence on the effect of IFRS adoption on investment management in Europe; Section 3 summarises existing literature on the effect during adverse economic conditions i.e. crisis period; Section 4 presents existing literature on the Effect of IFRS adoption on investment management worldwide and Section 5 concludes.

\section{The Impact of IFRS Adoption on Investment Management: A European Perspective}

There is extensive literature examining the general issue of the economic consequences of mandated changes of accounting standards worldwide. There is also, the stream of research exploring the economic consequences of the mandatory adoption of IFRS especially in Europe ${ }^{1}$. We present evidence of prior literature relating the consequences of IFRS mandatory adoption and investment decisions. We start by presenting evidence under a European setting. The key points, research questions, sample and main findings of these studies are summarized in Table 1.

L. M.-Ramos (2008) [1] presented empirical evidence "that the accounting harmonization process in Europe is a way to reduce information costs and unfamiliarity between countries and, therefore, an important way of encouraging international trade and foreign direct investments (FDIs)". He provided, from a macroeconomic perspective, empirical findings on the IFRS adoption effect in Europe, (as is shown in Table 1). After the establishment of accounting harmonization, there is a reduction in information costs and risks of conducting busi-

${ }^{1}$ As of 2005, it is required by firms listed in countries of the European Union (EU) to prepare their consolidated financial statements based on the requirements of the International Financial Reporting Standards (IFRS). 
ness with unfamiliar partners and "companies in different countries are expected to participate in foreign activities to a greater extent". Furthermore, this study also examined the adoption of IFRS considering uncertainty aversion diversity in countries and provided evidence that "uncertainty-averse countries benefit the most from IFRS adoption in terms of FDI, since the improvement of accounting information, in turn, fosters financial transparency and comparability, and reduces information asymmetries and unfamiliarity among agents in different countries". In brief, this means that harmonization of high quality accounting standards can be regarded as a strategy to reduce the perceived risks of investing abroad and to foster trade and FDI.

T. Schleicher, A. Tahoun and M. Walker (2010) [2] focused on an outcome of IFRS adoption rather than expected outcomes in the countries of the European Union (EU). They examined regarding investment efficiency, "which types of firms within which types of economies benefited most from IFRS adoption". They also explored the economic consequences related to the mandatory adoption of IFRS in EU countries by presenting the types of economies having the largest reduction in sensitivity of investment-cash flow during post-IFRS adoption period. They also explored "whether the reduction in investment cash flow sensitivity depends on firm size as well as economy type". Furthermore, their study relates to the research examining the relationship between financial market development and economic growth. Economic growth is facilitated by developed financial markets. Overall, the results of this study suggested that IFRS adoption may "have improved the functioning of capital markets in relation to small firms in insider economies" and that investment cash flow sensitivity is lower in outsider economies than that of insider economies, (as is shown in Table 1).

S. Lenger, J. Ernstberger and J. Stiebale (2011) [3], investigated the effect of adopting IFRS on European public and private firms' investment efficiency. Considering that IFRS adoption is related with higher accounting quality and that the higher-quality financial reporting fosters efficient firm investment, they examined the real business effects of applying IFRS in terms of firms' investment efficiency. They found that IFRS accounting is associated with a lower degree of overinvestment. They also documented that enforcement plays a positively significant role on the impact of the IFRS adoption on the financial reporting system and as a result on the firms' investment efficiency. Overall S. Lenger, J. Ernstberger and J. Stiebale (2011) [3], demonstrated that IFRS adoption is positively associated with higher accounting quality, which fosters efficient firm investment (as is shown in Table 1). Finally, this study contributed to recent empirical research with the results that IFRS has real business effects, especially for public firms. Also, IFRS accounting is associated with a higher degree of investment efficiency, and in general IFRS influences capital market properties.

P. André, A. Filip and S. Marmousez (2014) [4] examined the relationship between conservatism, which can be considered one of the dimensions of finan- 
cial reporting quality, and investment efficiency using dataset of French firms before and after the mandatory adoption of IFRS in 2005. The objective of this research is to test whether conservatism, an important quality factor of financial reporting, is associated with greater investment efficiency, or in other words with lower over- or under-investment, before and after the mandatory application of IFRS in 2005.

C. Chen, D. Young, and Z. Zhuang (2013) [5], examined the externalities of mandatory IFRS adoption on the investment efficiency of firms from 17 European countries. They investigating the spillover effects of a firm's ROA difference versus its foreign peers and improved disclosure of foreign peers on the firm's investment efficiency. They supported with their results that after IFRS adoption, the spillover effect of the firm's ROA difference in comparison to its foreign peers on reducing the firm's under- or overinvestment is increased (as is shown in Table 1). In addition, it is provided that the improved disclosure by a firm's foreign peers under IFRS also has a spillover effect on reducing the firm's under- or overinvestment. Furthermore, they also found that investment changes induced by greater disclosure by foreign peers under IFRS are value relevant. Overall, C. Chen, D. Young, and Z. Zhuang (2013) [5], contributed to the literature supporting the positive externalities of IFRS regulation on firms' investment efficiency, with additional findings that legal enforcement strength, composition of peer firms, and industry competition environments affect significantly the spillover effects.

Productivity is the efficiency in production and is measured by how much output is obtained from a given set of inputs. Academic literature has presented long research effort focusing on measuring productivity and addressing productivity differences across businesses. Some studies associate productivity with firm-specific internal drivers such as managerial talent, quality of capital inputs and general labor, R \& D investment and information technology, product innovation and firm structure decisions and some other studies with external drivers such as technology spillovers, competition, flexible input markets, and deregulation. It is considered that the quality of accounting standards as an infrastructure of financial markets, and the resulting financial reporting can impact productivity through project identification, but there is limited evidence on how changes in financial reporting regimes and accounting standards may affect productivity. IFRS adoption has many positive effects like it leads to increased disclosure and transparency, which means lower information asymmetry and easier access to equity financing, and improves the efficiency of contracting between firms and managers, which means impelling managers to take action in the best interests of shareholders. Summarizing and going forward, IFRS adoption increasing comparability and transparency, may lead to increased shareholding by institutional investors and foreign mutual funds, more efficient relative performance evaluation, and increased product market competition.

Therefore, based on the previous reasoning, R. D. Banker, R. Huang and Y. Li 
(2014) [6] investigated the association between productivity improvement and changes in accounting standards and support that firm productivity improves after mandatory adoption of IFRS. They studied the association between productivity and accounting standard quality in the framework of mandatory IFRS adoption. They used revenue as the output measure and cost of inventory, general and administrative expenses, fixed assets, past $\mathrm{R} \& \mathrm{D}$ expenditures, and intangible assets as input measures of production efficiency. R. D. Banker, R. Huang, and Y. Li, (2014) [6], conjectured that productivity may improve after mandatory IFRS adoption due to lower information asymmetry, easier access to equity financing, better contracting mechanisms, and increased comparability, (as is shown in Table 1). Their empirical results also indicated "that the production efficiency of mandatory IFRS adopters increases significantly after mandatory adoption". They further documented that in countries with large GAAP differences, in the post IFRS adoption period production efficiency is further improved, stock return volatility is reduced and analyst forecast dispersion is also decreased and the number of comparable industry peers is significantly increased. Overall, the total evidence suggested that firms with significant improvements in their information reporting environment from mandatory IFRS adoption are able to increase productivity substantially.

Firm production efficiency increases more for those firms that have reduced information asymmetry and increased comparability after the adoption, since financial statement transparency facilitates also equity financing, compensation contracting, and decision-making.

As extensively referred accounting harmonisation has positive effect on firm productivity but also to other economic dimensions. Improving accounting standards harmonisation worldwide has as consequence the reduction of the perceived risks of investing abroad. The IFRS adoption reduces information costs among countries, gives more opportunities for international trade in goods and investments and concurrently improving financial reporting quality fosters trade and FDIs. Specifically, the accounting harmonisation process in Europe intends to reduce information costs and unfamiliarity between European countries so as to improve international trade and foreign direct investments.

Considering heterogeneity issues among the European Union countries of and their uncertainty aversion diversity, L. M.-Ramos (2011) [7], studies this accounting harmonisation process in Europe. This study provided evidence that transition economies gained the most benefit from IFRS adoption regarding trade in goods in the period following 1999 (as is shown in Table 1). In addition to that there are countries that gained the most benefit from the IFRS adoption regarding trade in goods due to the fact that IFRS have different implementation and interpretation in countries with different legal systems. Moreover, L. M.-Ramos (2011) [7], provided evidence that "uncertainty-averse countries benefit the most from IFRS adoption in terms of FDI" and that the "information asymmetries between neighbouring countries and countries sharing recent colo- 
Table 1. The impact of IFRS adoption on investment management: a European perspective.

\begin{tabular}{|c|c|c|c|}
\hline Authors & Research question & Sample & Main findings \\
\hline $\begin{array}{l}\text { André, Filip } \\
\text { and } \\
\text { Marmousez } \\
(2014)[4]\end{array}$ & $\begin{array}{l}\text { Examine the relationship between } \\
\text { conservatism, a dimension of financial } \\
\text { reporting quality, and investment } \\
\text { efficiency. } \\
\text { - Test whether a higher degree of } \\
\text { conservatism, and of financial reporting, } \\
\text { is associated with a greater investment } \\
\text { efficiency, or with lower over- or } \\
\text { under-investment. }\end{array}$ & $\begin{array}{l}\text { - Sample of French firms } \\
\text { with } 787 \text { using French } \\
\text { GAAP and } 839 \text { using } \\
\text { IFRS. }\end{array}$ & $\begin{array}{l}\text { - Conservatism significantly declines after the move } \\
\text { to IFRS. } \\
\text { - In the pre-IFRS period, conservatism limits over- } \\
\text { or underinvestment. } \\
\text { - The quality of accruals (financial reporting } \\
\text { quality), plays an important role over the whole } \\
\text { study period (pre- and post-IFRS) in disciplining } \\
\text { investment, and this role grows with the adoption } \\
\text { of IFRS. }\end{array}$ \\
\hline $\begin{array}{l}\text { Banker, Huang, } \\
\text { and } \operatorname{Li}(2014) \\
{[6]}\end{array}$ & $\begin{array}{l}\text { - Examine whether productivity improves } \\
\text { after mandatory IFRS adoption. }\end{array}$ & $\begin{array}{l}\text { - Sample of mandatory } \\
\text { IFRS adopters of } 16 \\
\text { countries and } 9485 \text { firm } \\
\text { year observations and } \\
\text { voluntary IFRS adopters } \\
\text { of } 15 \text { countries of } 49,345 \\
\text { firm year observations. }\end{array}$ & $\begin{array}{l}\text { - Production efficiency of mandatory IFRS adopters } \\
\text { increases significantly after mandatory IFRS adoption. } \\
\text { - Firms located in countries with large GAAP } \\
\text { differences, firms exhibiting a decrease in stock } \\
\text { return volatility and analyst forecast dispersion and } \\
\text { firms experiencing a large increase in the number } \\
\text { of comparable industry peer, in the post IFRS } \\
\text { adoption improve more the production efficiency. } \\
\text { - Firms with significant improvements in their } \\
\text { information environment from mandatory IFRS } \\
\text { adoption are able to increase productivity substantially. }\end{array}$ \\
\hline $\begin{array}{l}\text { Chen, Young, } \\
\text { and Zhuang } \\
\text { (2013) [5] }\end{array}$ & $\begin{array}{l}\text { - Examine the externalities of mandatory } \\
\text { IFRS adoption on firms' investment } \\
\text { efficiency. } \\
\text { - Examine whether mandatory IFRS } \\
\text { adoption in Europe enhances the } \\
\text { spillover effects of foreign peers' } \\
\text { accounting information on the firm's } \\
\text { investment efficiency. }\end{array}$ & $\begin{array}{l}\text { - Sample of } 17 \text { European } \\
\text { countries in } 8857 \text { firm } \\
\text { year observations from } \\
2000 \text { to } 2009 \text {. }\end{array}$ & $\begin{array}{l}\text { - Firms' investment efficiency improves following } \\
\text { IFRS adoption. } \\
\text { - The spillover effect of a firm's ROA difference } \\
\text { versus its foreign peers, but not domestic peers, on } \\
\text { the firm's investment efficiency increases after } \\
\text { IFRS adoption. } \\
\text { - IFRS adoption improving information } \\
\text { comparability and disclosure enable managers and } \\
\text { investors to use accounting information of foreign } \\
\text { peers more effectively. Such improved information } \\
\text { can help managers to make better investment } \\
\text { decisions and help investors to effectively evaluate } \\
\text { and monitor firms' investment. }\end{array}$ \\
\hline $\begin{array}{l}\text { Lenger, } \\
\text { Ernstberger } \\
\text { and Stiebale } \\
(2011)[3]\end{array}$ & $\begin{array}{l}\text { Examines the impact of adopting IFRS on } \\
\text { European public and private firms' } \\
\text { investment efficiency. }\end{array}$ & $\begin{array}{l}\text { - Sample of } 10 \text { countries of } \\
\text { EU with } 142,873 \text { firms } \\
\text { and } 951,650 \text { firm year } \\
\text { observations from } 1998 \text { to } \\
2008 .\end{array}$ & $\begin{array}{l}\text { - Mandatory IFRS application has more pronounced } \\
\text { effects for public firms' investment efficiency and } \\
\text { benefits are higher for public firms in a. } \\
\text { - The impact of the IFRS adoption combined also } \\
\text { with the enforcement influence positively the } \\
\text { financial reporting system and as a result the firms' } \\
\text { investment efficiency. }\end{array}$ \\
\hline $\begin{array}{l}\text { Ramos (2008) } \\
{[1]}\end{array}$ & $\begin{array}{l}\text { - Study the importance of accounting } \\
\text { harmonization on foreign activities from } \\
\text { a macroeconomic perspective, by } \\
\text { focusing on the importance of European } \\
\text { accounting harmonization on } \\
\text { international trade and foreign direct } \\
\text { investments (FDI). }\end{array}$ & $\begin{array}{l}\text { - Sample } 27 \text { EU countries } \\
\text { plus United States, China, } \\
\text { Japan, EFTA members } \\
\text { and Croatia, Turkey from } \\
1999 \text { to } 2007 \text { as well as data } \\
\text { on bilateral FDI flows } \\
\text { (namely investments by } \\
\text { resident entities in } \\
\text { affiliated enterprises } \\
\text { abroad) for } 1999 \text { to } 2006 \text {. }\end{array}$ & $\begin{array}{l}\text { - IFRS adoption benefit and FDI. } \\
\text { Positive effect of adopting uniform accounting } \\
\text { standards on foreign activities in Europe is higher } \\
\text { in transition economies. }\end{array}$ \\
\hline
\end{tabular}




\section{Continued}

Ramos (2011) - Examines the importance of accounting [7] harmonization on foreign activities at a macroeconomic level.
Schleicher,

Tahoun, and

Walker (2010)

[2]
- Examine the economic consequences of the mandatory IFRS adoption in the EU countries by showing which types of economies have the largest reduction in investment-cash flow sensitivity post-IFRS.

- Examine whether the reduction in investment cash flow sensitivity depends on firm size as well as economy type.
- Sample 27 EU countries - IFRS adoption benefits trade in goods and FDI. plus United States, China, • Positive effect of harmonizing accounting Japan, EFTA members standards on foreign activities in Europe differs in and Croatia, Turkey from countries because of behavioral factors such as 2002 to 2007, as well as unfamiliarity aversion.

data on bilateral FDI

flows (namely

investments by resident

entities in affiliated

enterprises abroad).

- Sample of 6 EU countries - The investment cash flow sensitivity of higher with 5655 firm year observations from periods 2000-2004 and 2005-2007. economies is higher than that of outsider economies pre-IFRS

- IFRS adoption reduces the investment cash flow sensitivity of insider economies more than that of outsider economies.

- Insider economies have higher investment cash flow sensitivity using both current and lagged cash flow.

- IFRS adoption may have improved the functioning of capital markets in relation to small firms in insider economies.

nial links are less pronounced prior to IFRS adoption and, therefore, the benefits of IFRS adoption are lower". Finally, L. M.-Ramos (2011) [7] proposed that there is a need for further research due to diversity in the implementation process of mandatory IFRS adoption in European countries in the accounting harmonisation process, and in the dominant reporting choice among listed firms before 2005 which had significant consequences regarding trade in goods and FDI.

To summarize: IFRS adoption in Europe improved accounting harmonization, fostered international trade and foreign direct investments (FDIs) by reducing information asymmetry, information cost, unfamiliarity between countries and improving transparency and comparability (L M-Rammos (2008) [1]). IFRS adoption in European Union had positive effects on investment efficiency, especially for large firms and outsider economies, where investment cash flow sensitivity is lower than inside economies (T. Schleicher, A. Tahoun and M. Walker (2010) [2]). IFRS adoption also is positively associated with higher accounting quality, which fosters efficient firms' investment, lowers overinvestment and positively influences capital markets (S. Lenger, J. Ernstberger, J Stiebale (2011) [3]). Mandatory IFRS adoption significantly increases production efficiency, which in turn reduces stock return volatility and the number of comparable industry peers is significantly decreased. Firm production efficiency is more enhanced for IFRS adopters (R. D. Banker, R. Huang, Y. Li (2014) [5]). Accounting harmonization process in Europe had significant positive effects in trade of goods but the heterogeneity among European countries in terms of implementation process needs to be explored by further research (L. M-Rammos (2011) [6]). 


\section{The Effect of European Crisis on Investment Management}

Additional to the extensive literature of European accounting harmonization with IFRS adoption, there is also a stream of literature exploring the economic effects of the recent European crisis. The European debt crisis and especially "the Eurozone crisis is a debt crisis that has been taking place in the European Union". It is well accepted that the crisis was merely apparent during the period 2008-2010. However, even still several Eurozone member states (Greece, Portugal etc.) are in national supervision or recession, since after the crisis they "were unable to repay or refinance their government debt or to bail out over indebted banks under their national supervision without the assistance of third parties like other Eurozone countries, the European Central Bank (ECB), or the International Monetary Fund (IMF)". We present a number of studies that have explored the effects of the crisis in the investment performance of firms. The key points; authors, research questions, sample and main findings of these studies are presented in brief in Table 2.

M. Campello, E. Giambona, J. R. Graham and C. R. Harvey (2012) [8] reported that "the recent crisis did not severely hinder firms' ability to access lines of credit and draw down existing facilities". This proved to be of utmost importance for European companies as credit lines from banking sector became an essential way of financing and eased the financial crisis effect on investment and firm's financial performance, (as is shown Table 2).

Additionally, S. L. Boumediene, O. Nafti and E. Boumediene (2014) [9] studied the impact of the economic crisis on the informational content of accounting information based on the IFRS financial reporting system adopted by France. They examined the correlation relationship between discretionary accruals and accounting and financial in France before and after the crisis. They found that before the crisis the IFRS adoption "affects negatively the relationship between the yield of the French listed companies and the proportion of assets turnover" (as is shown Table 2). They further report that "for the period after the crisis, the results show that French listed firms did not enter into new long-term investment process, but are more interested in increasing their turnover and keeping their customers". They proposed that future research can include more European Union (EU) countries to examine the effect of IFRS adoption during the 2008 crisis on the relationship between yield and accounting variables.

H. Balfoussia and H. D. Gibson (2016) [10], examined the association between overall financial conditions and corporate investment in countries of the euro area. Furthermore, they examined whether the well-documented investment cash flow sensitivity arising from the external financing premium of constrained firms varies over time and with overall financial conditions. Their results suggested that "financial conditions have indeed played a significant role in corporate investment decisions over recent years, rendering financing constraints even more binding", (as is shown Table 2). Additionally, they found that the effect of 
Table 2. The effect of European crisis on investment management.

\begin{tabular}{|c|c|c|}
\hline Authors & Research question & Sample \\
\hline $\begin{array}{l}\text { Balfoussia and } \\
\text { Gibson, (2016) [10] }\end{array}$ & $\begin{array}{l}\text { Explore whether the sensitivity of } \\
\text { firm-level investment to cash-flow, } \\
\text { typically associated with an external } \\
\text { financing premium, is time-varying } \\
\text { and in particular whether it varies } \\
\text { with overall financial conditions. }\end{array}$ & $\begin{array}{l}\text { - Sample of } 2400 \text { listed } \\
\text { companies in EU for period o } \\
1980 \text { to } 2013 \text {. }\end{array}$ \\
\hline $\begin{array}{l}\text { Boumediene, Nafti, } \\
\text { and Boumediene, } \\
(2014)[9]\end{array}$ & $\begin{array}{l}\text { Test the impact of the financial } \\
\text { crisis on the informational content } \\
\text { of accounting numbers. }\end{array}$ & $\begin{array}{l}\text { Sample of } 220 \text { firm year } \\
\text { observations on the French } \\
\text { stock market and periods } \\
\text { 2006-2007 and 2009-2011. }\end{array}$ \\
\hline
\end{tabular}

Campello, Giambona, • examine how firms in Europe used Graham, and Harvey (2012) [8] credit lines during the financial crisis.
- Two surveys at approximately 10,500 e-mail invitations to CFOs in Europe and North America. At survey 1 in 2009 Q1 responded 580 and at survey 2 in 2009 Q2 responded 565 .
Doukakis, Kapellas and Siougle (2017) [11]
- Examine the impact of IFRS adoption on investment decisions in Europe

- Examine if the impact of IFRS on investment decision differentiates under adverse economic conditions i.e. crisis period
- Sample of 18 European countries. Study period 2000-2012. Total sample of 1480 sample firms; 341 voluntary adopting firms and 1139 mandatory adopting firms
- Financial conditions have indeed played a significant role in corporate investment decisions over recent years, rendering financing constraints even more binding.

- The impact of credit conditions is not uniform across firms, but rather it varies depending on firm size and leverage, with constrained firms being substantially more likely to condition their investment decisions on overall credit conditions.

- The 2008 financial crisis contributed to reducing the information content of accounting numbers due to lack of confidence created by investors towards the information published on the basis of international standards.

- Firms with restricted access to credit (small, private, non-investment-grade, and unprofitable) draw more funds from their credit lines during the crisis than their large, public, investment- grade, profitable counterparts.

- Interest spreads increased (especially in "market-based economies"), but commitment fees remained unchanged.

- Credit lines did not dry up during the crisis and provided the liquidity that firms used to cope with this exceptional contraction.

- Credit lines provided the liquidity companies needed to invest during the crisis.

- The financial reporting practices of mandatory versus voluntary adopters cause significant differences in (a) the cost of equity capital, (b) the level of capital investments and (c) the return on invested capital.

- These evidence are more pronounced under the strong legal enforcement environment

- During the crisis period the cost of equity capital was increased for both voluntary and mandatory adopters. Both groups seem to keep their investment policy unchanged even under adverse economic conditions

credit conditions varies among firms depending on firm size leverage and constrained firms are considerably more likely to condition their investment decisions on overall credit conditions. H. Balfoussia and H. D. Gibson (2016), contributed to the academic literature regarding the interaction between financial and real cycle downturns.

L. Doukakis, K. Kapellas and G. Siougle (2017) [11] examined the effect of 
IFRS adoption on investment decisions for European countries. Within their study period (2000-2012) they further explore whether capital investment decisions were influenced by the adverse economic crisis conditions that took place in the Eurozone in years 2008-2010. Their empirical finding support that during the crisis period the cost of equity capital was increased for voluntary and mandatory IFRS adopters and that investment strategy for both groups seems to remains sustainable even under adverse economic conditions, (as is shown Table 2).

To summarize: Even during financial crisis, European companies continued to have credit lines from the banking sector financing their investments and maintaining their financial performance M. Campello, E. Giambona, J. R. Graham and C. R. Harvey (2012) [8]). French listed firms during crisis were interested in keeping their customers and increasing their assets turnover, than participating in new long term investment projects (S. L. Boumediene, O. Nafti and E. Boumediene (2014) [9]). During financial crisis the effect of credit conditions varies among firms depending on firm size leverage. Additionally, financial constrained firms are more likely to condition their investment decisions on overall credit conditions (H. Balfoussia and H. D. Gibson (2016) [10]). During the crisis period the cost of equity capital was increased for voluntary and mandatory IFRS adopters and the investment strategy of both groups seemed to pertain even under adverse economic conditions (L. Doukakis, K. Kapellas and G. Siougle (2017) [11]).

\section{The Effect of IFRS Adoption on Investment Management Worldwide}

International financial reporting standards (IFRS) have been also adopted by countries outside the European Union for financial reporting purposes. The adoption of IFRS may improve the informational environment if the change from local GAAP (Generally Accepted Accounting Principals) to IFRS brings higher quality financial reporting and lower information asymmetries among countries. Therefore, a question arises whether the adoption of IFRS results in worldwide economic benefits. We present evidence from studies using extended international samples. The key points and main findings of these studies are briefly presented in Table 3.

A. Florou and P. F. Pope (2012) [12], examined "whether the mandatory introduction of IFRS leads to an increase in institutional investor demand for equities" and they found that "institutional holdings increase for mandatory IFRS adopters". The IFRS adoption leading to higher financial reporting quality, has significant benefits on institutional holdings, (as is shown in Table 3). This study also showed that "increased institutional holdings are concentrated in countries where enforcement and reporting incentives are strongest and where the differences between local GAAP and IFRS are relatively high".

Prior relevant academic research suggested that information asymmetry be- 
tween local and foreign investors and behavioral biases due to unfamiliarity of the foreign markets drive investors preferring to invest in their home markets. For this purpose, one of the goals of the adoption of IFRS is to establish a high quality, worldwide familiar set of accounting standards. Following this and based on the familiarity of IFRS, D. Amiram (2012) [13] predicted that foreign investments will increase in countries that adopted IFRS after the transition to IFRS. He investigated the relationship between IFRS adoption and foreign investment decisions and found that foreign equity portfolio investments (FPI) show an increase in IFRS adopting countries, (as is shown in Table 3). More importantly, he found that "this relation is driven by foreign investors from countries that also use IFRS".

Furthermore, a primary motivation for creating IFRS was to increase capital investment efficiency as elucidated by the International Accounting Standards Board Chairman David Tweedie: “As the world's capital markets integrate, the logic of a single set of accounting standards is evident. A single set of international standards ... should make the allocation of capital ... more efficient' [emphasis added] (Tweedie 2006).

Focusing directly on the realization of this benefit, G. C. Biddle, C. M. Callahan, H. Hong, and R. L. Knowles (2011, March 1, 2013, August 31, 2015) [14], examined whether IFRS enhances firm-level capital investment efficiency. Specifically, they examined the mandatory IFRS adoption effect on the economic fundamental of firms' capital investment decisions and if there is an improvement in firm level capital investment efficiency using data from 26 countries. They focused on the examination of the associations between IFRS adoptions and two measures of firm-level capital investment efficiency: "investment-cash flow sensitivity and value-enhancing risk taking". The former is a classic measure of investment efficiency in the corporate finance literature. They also investigated the differential effect of investment efficiency associated with the countries' legal and political environment as well as the financial transparency and ownership concentration after the mandatory IFRS adoption. They found that "firms' investment policy is associated with a shift towards a risk-adjusted optimal level while their investment-cash flow sensitivity decreases" and "this association is more pronounced in countries with weak law enforcement institutions and higher ownership concentration". Finally, they concluded that the increased financial disclosure and financial statements comparability, after the IFRS adoption benefit outside capital providers and thus lead to improved investment efficiency at the firm-level, which is globally an issue of high importance to firm managers and regulators, (as is shown in Table 3).

H. Louis and O. Urcan (2014) [15] examined "whether the mandatory adoption of IFRS leads to an increase in cross-border acquisitions into the adopting countries and whether there is any effect by concurrent enforcement changes". They found that after IFRS adoption there is a significant increase in the odds of a cross-border acquisition for a listed firm in the adopting countries, whereas for 
an unlisted firm the change in the odds is insignificantly different from zero,, (as is shown in Table 3). Additionally, their findings supported that the increase in the flow of "investment into the IFRS adopting countries comes from both non-IFRS adopting countries and other IFRS adopting countries" and "that the mandatory adoption of IFRS leads to a substantial increase in cross-border acquisitions of listed companied in the adopting countries".

IFRS introduction has been the largest reporting standards change in accounting history since a continuous large number of countries move to this trend. Mandatory reporting under IFRS has been examined extensively but of utmost significance to researchers, policy makers, and regulators has been also a better understanding of the sources that led to the observed capital market benefits. A number of these benefits presented in current literature are related to improvements in foreign (cross-border) investments, favorable liquidity effects and a reduction in the cost of equity capital, which eventually results in improvements in investment returns and efficiency. The debate on mandatory accounting harmonization is an open issue.

On the one hand mandatory regulatory intervention yield key benefits based on the argument that accounting quality is determined by accounting standards. The international comparability of financial statements should improve through the adoption of a common accounting "language". This should ease cross-border capital flows and hence reduce the cost of capital. On the other hand, the quality of financial reporting is more affected by preparers' incentives and institutional context than by accounting standards. Even in the same country, there are differences between firms regarding the extent of reliance on external funding and their cost of compliance with financial disclose requirements. Companies that have little to gain from IFRS may decide to make use of any embedded flexibility in IFRS implementation. Academic research also showed some evidence that the voluntary adoption of IFRS reduces the cost of equity capital, but the results of the empirical research about the economic consequences of mandatory adoption remain unclear.

U. Brüggemann, H. Daske, C. Homburg and P. F. Pope (2012) [16], analyzed the effect of global IFRS adoption on cross-border equity investment by individual investors. Individual investors tend to be less sophisticated than their institutional peers. This study predicted that individual investors focus on those stocks within the IFRS. Following these assertions individual investors are expected to ignore the complex interaction between IFRS adoption and the institutional stock environment. The empirical results of their study suggested "that stocks experience a significant increase in Open Market trading volume following mandatory adoption of IFRS" and that "global IFRS adoption enhances cross-border equity investments by individual investors", (as is shown in Table 3).

High uniformity in accounting standards imposes less information cost on foreign acquirers and enables them to better value target firms and monitor for- 
eign investments, improving cross-border mergers and acquisitions. Advancing prior literature regarding the consequences of differences in accounting standards worldwide, J. R. Francis, S. X. Huang and I. K. Khurana (2012) [17], investigated whether differences in accounting standards across countries restrain firms from investing in foreign markets. They provided evidence "that the volume of $\mathrm{M} \& \mathrm{~A}$ activity across country pairs is larger for pairs of countries with similar GAAP", and "that the takeover premium is higher if target countries' GAAP is similar to that of the acquiring firm's country" (as is shown in Table 3). They further demonstrated that mandatory IFRS adoption "attracted more cross-border M \& As among IFRS adopting countries, and that this increase in M \& A activity within the IFRS countries is more pronounced for country pairs with low degree of similarity in GAAP in the pre-IFRS adoption period".

Following the intuition that comparability of financial statements is among the most important issues for global investors, M. DeFond, X. Hu, M. Hung and S. Li (2011) [18], examined the effect of adopting a uniform set of accounting standards like the mandatory IFRS adoption on comparability and cross-border investment. They investigated the change in foreign mutual fund investment for firms that started using IFRS after its mandatory adoption in the European Union (EU) in 2005. Empirical evidence of this study suggested that mandatory adoption of IFRS increased more foreign investment among companies in countries with strong implementation credibility and significant advances in uniformity. Furthermore, according to additional analysis the enhanced comparability associated with mandatory IFRS adoption does not increase domestic mutual fund ownership as domestic investors are more familiar with local accounting standards,, (as is shown in Table 3). They also identified that "the increase in foreign mutual fund ownership in response to improved comparability is primarily driven by foreign global mutual funds".

M. DeFond, X. Hu, M. Hung and S. Li (2011) [18] complement and extend prior relevant literature by investigating whether the role of uniformity leads to improved financial statement comparability. The change in the financial reporting environment after a country's adoption of IFRS is likely to increase the transparency of financial reports and lead businesses and individuals in other countries to invest in the adopting country.

L. A. Gordon, M. P. Loeb and W. Zhu (2012) [19] investigated the impact of IFRS adoption on the overall country FDI inflows and whether this impact varies for developing or developed economies. They provided evidence that there exists a positive association between overall FDI inflows and a country's IFRS adoption (as is shown in Table 3). These results are more significant for countries characterized as developing economies rather than for those countries characterized as developed economies. Furthermore, they identified the country's desire to receive financial support from the World Bank as another incentive for IFRS adoption by countries with developing economies. Overall, L.A. Gordon, M. P. Loeb and W. Zhu (2012) [19] provided evidence into clarifying the relationship 
a) between overall FDI inflows and the country's accounting standards and b) between the ability of a country characterized as developing economy to receive loans from international organizations like the World Bank and the accounting standards used by that country. They proposed that future research should examine the above issues as countries become more experienced with the use of IFRS.

C. P. Chen, Y. Ding and B. Xu (2014) [20] examined the relationship between FDI activities and convergence of accounting standards and tested the effect of IFRS adoption on changes in FDI flows between countries. Cross-border investments are promoted by the adoption of a set of common financial reporting standards by reducing the information barrier to FDI. They found a positive association between FDI flows and conformity to IFRS, which is stronger for country pairs with greater institutional differences, (as is shown in Table 3). This study also showed that "accounting information is relevant to FDI decisions and the adoption of IFRS is not just a change of label, but a more profound mutation that fosters lower transaction costs and better transparency".

Trying to verify that the IFRS adoption promised a greater cross-border investment and as a consequence a more efficient capital allocation, G. Lee and N. Fargher (2010) [21], investigated whether the mandated adoption of IFRS brings potential benefits to investors. Specifically, they examined the effect of the IFRS adoption on the international diversification of Australian investors and provided evidence that the mandatory IFRS adoption encouraged greater foreign investment for investors. This study supported that investors are benefited from the IFRS adoption, which is associated with greater cross-border equity investments, increase in the comparability of financial reports among capital markets and information asymmetry reduction (as is shown in Table 3). They proposed for future research the examination of the IFRS adoption impact on the usefulness of financial statements to other users except investors, such as credit analysts, equity analysts, debt holders and internal managers.

I. K. Khurana and P. N. Michas (2011) [22], investigated whether mandatory IFRS adoption at the country level reduces US investors' bias against investments in foreign countries, since investors tend "to overweight domestic stocks in their common stock portfolios". They provided evidence that US home bias is lower for countries that mandate IFRS adoption, (as is shown in Table 3). Particularly, they found that the reduction in the US home bias following the mandatory IFRS adoption is greater "for countries with larger differences between IFRS and their domestic accounting standards", "for countries with a stricter rule of law, a common law legal origin" and "in countries with greater incentives to report high-quality financial information". This bias reduction is not driven by the EU countries. Additionally, the authors provided empirical evidence "that a common set of global accounting standards matter for portfolio holdings of US investors" as they consider the enforcement of standards to be an important factor for making investments outside the US. 
The recent global trend towards the use of IFRS signals reduction of information asymmetries for international investors. A stronger regulatory environment should accompany these standards so as to gain legitimacy. The legal standards system and the enforcement regime are significant for the establishment of accounting standards, which are important for US investors making portfolio allocations in foreign equities.

K. M. Shima and E. A. Gordon (2011) [23], investigated whether there exist an association between a country's use of IFRS and increased US investment in foreign equities. They found a positive association between US investment and IFRS adoption "only when it is combined with a strong regulatory environment, specifically a strong enforcement regime", (as is shown in Table 3). They determined two dimensions of the regulatory environment, legal standards system and enforcement regime and concluded that "both factors individually and when interacted with IFRS are associated with US foreign investment".

H. A. Hong, M. Hung and G. J. Lobo (2014) [24] examined the consequences of the mandatory IFRS adoption for IPOs. Particularly, they examined the impact of mandatory IFRS adoption on IPO underpricing and capital source in global markets. Their results supported the existence of a statistically and economically significant a) "reduction in IPO underpricing following mandatory IFRS adoption" and b) "increase in the amount of capital raised from foreign markets". They also found that the above relations are higher for firms in countries experiencing large accounting changes and are more evident among firms in countries with strong implementation credibility (as is shown in Table 3). Thus they supported that the effect of IFRS adoption depends on country-level institutions, accounting differences, and implementation credibility. Furthermore, regarding the effect of mandatory IFRS adoption on IPO underpricing for domestic and global IPOs, it is noted that the decrease in underpricing for global IPOs is more pronounced than it is for domestic IPOs, since foreign investors face greater information asymmetry than domestic investors, and thus benefit more from improved financial reporting.

Differences in disclosure requirements and financial reporting standards across countries create information barriers that create obstacles to cross-border capital flows and investments. Cross-listings are important as they ease crossborder capital flows and promote the integration of global financial markets. The adoption of a single set of global high-quality accounting standards could reduce cross-border accounting information and regulatory barriers, thereby facilitating cross-border investment.

An increasing body of literature examining the economic consequences of mandatory IFRS adoption has raised the question of whether this adoption facilitates firms' cross-border stock-listing activities. L. Chen, J. Ng and A. Tsang (2015) [25] examined the effect of mandatory IFRS adoption on firms' crosslisting activities. The results of their study shed light on the way mandatory IFRS adoption changes the geography of cross-listings around the world and provided 
evidence that the effect of mandatory IFRS adoption on a firm's cross-listing activities varies "with the institutional characteristics of the firm's home country". In particular, they found that mandatory IFRS-adopters compared to non-IFRS adopters, experience a larger increase in the likelihood to cross-list, as well as a larger increase in the number of cross-listing target countries after mandatory IFRS adoption (as is shown in Table 3). Moreover, L. Chen, J. Ng and A. Tsang (2015) [25], noticed, as in most studies that exploit an exogenous event, that it is hard to examine the effect of mandatory IFRS adoption on cross-listings unambiguously and causally attribute the observed effects to the event of interest. For example, the EU countries have initiated several directives aimed at integrating the European capital markets, including IFRS, to facilitate cross-listings of EU firms, and these initiatives occur at the same time of the mandatory IFRS adoption. This means that additional academic research is required on the economic consequences of mandatory IFRS adoption to explore the question whether it facilitates firms' cross-border stock-listing activities, so as to be able to provide more confident empirical results.

To summarize: Mandatory IFRS adoption increased the institutional investors demand for equities and additionally more for countries with strong legal enforcement environment and high reporting incentives (A. Florou and P. F. Pope (2012) [12]). Foreign equity portfolio investments (FDIs) increased due to the increase of familiarity and reduction of asymmetry (D. Amiran (2012) [13]). IFRS adoption enhances firm-level capital investment efficiency and this relation is further affected by financial transparency and ownership concentration as well as the legal and political environment. IFRS adoption increases financial disclosure and financial statements comparability, which in turn benefit outside capital providers, leading to improved firm-level investment efficiency (G. C. Biddle, C. M. Callahan, H. Hong, and R. L. Knowles (2011, March 1, 2013, August 31, 2015) [14]). Mandatory IFRS adoption leads to an increase in cross-border acquisitions, positively affected by the legal enforcement environment (H. Louis and O. Urcan (2014) [15]). Global IFRS adoption positively enhanced crossborder equity investments by individual investors (U. Brüggemann, H. Daske, C. Homburg and P. F. Pope (2012) [16]). The volume of M \& A activity across country pairs is larger for pairs of countries with high uniformity in accounting standards, which imposes less information cost on foreign acquirers. This increase in M \& A activity within the IFRS countries is more evident when there is low uniformity in accounting standards in the pre-IFRS adoption period (J. R. Francis, S. X. Huang and I. K. Khurana (2012) [17]). IFRS adoption is positively associated with overall country' FDI inflows. This positive association is more significant in countries with developing economies (L. A. Gordon, M. P. Loeb and W. Zhu (2012) [19]). IFRS adoption across countries leads to convergence of accounting standards which in turn improves familiarity, transparency, reduces transaction cost and as a result enhances FDI flows between countries (C. P. Chen, Y. Ding and B. Xu (2014) [20]). Mandatory IFRS adoption encouraged 
Table 3. The effect of IFRS adoption on investment management worldwide.

\begin{tabular}{|c|c|c|c|}
\hline Authors & Research question & Sample & Main findings \\
\hline Amiram (2012) [13] & $\begin{array}{l}\text { - Investigates the association between the } \\
\text { IFRS adoption and foreign investment } \\
\text { decisions. }\end{array}$ & $\begin{array}{l}\text { - Sample of } 105 \text { ( } 104 \text { in } \\
\text { table) countries of which } \\
53 \text { investor and } 81 \\
\text { investee countries with } \\
13,992 \text { country year } \\
\text { observations in } 2006 \text {. }\end{array}$ & $\begin{array}{l}\text { - Foreign investments increase in countries that } \\
\text { adopted IFRS and this increase is driven by the } \\
\text { familiarity of IFRS. } \\
\text { - Foreign equity portfolio investments (FPI) } \\
\text { increase in countries that adopt IFRS. } \\
\text { - Accounting information plays a role in foreign } \\
\text { portfolio investment decisions. } \\
\text { - Familiarity of accounting standards is the } \\
\text { source of association between IFRS adoption } \\
\text { and foreign investment decisions. }\end{array}$ \\
\hline $\begin{array}{l}\text { Biddle, Callahan, } \\
\text { Hong, and Knowles } \\
\text { (2011, March 1, } \\
\text { 2013, August 31, } \\
\text { 2015) [14] }\end{array}$ & $\begin{array}{l}\text { - Examine whether International } \\
\text { Financial Reporting Standards (IFRS) } \\
\text { enhanced firm-level capital investment } \\
\text { efficiency. } \\
\text { - Examine associations between IFRS } \\
\text { adoptions and two measures of } \\
\text { firm-level capital investment efficiency: } \\
\text { investment-cash flow sensitivity and } \\
\text { value-enhancing risk taking. }\end{array}$ & $\begin{array}{l}\text { - Sample of } 7220 \text { firms } \\
\text { from } 26 \text { countries and } \\
31,476 \text { firm year } \\
\text { observations from } 2001 \\
\text { to } 2008 \text { (August } 31 \text {, } \\
\text { 2015). }\end{array}$ & $\begin{array}{l}\text { - Mandatory IFRS adoption enhance capital } \\
\text { investment efficiency. } \\
\text { - After the mandatory adoption of IFRS, firms' } \\
\text { investment policy is associated with a shift } \\
\text { towards a risk-adjusted optimal level while their } \\
\text { investment-cash flow sensitivity decreases. } \\
\text { - The study (August 31, 2015) extends prior } \\
\text { findings that associations between IFRS } \\
\text { adoptions and capital investment efficiency are } \\
\text { stronger for countries with weaker legal systems } \\
\text { and protections, more concentrated corporate } \\
\text { ownership, and prior reporting standards that } \\
\text { differ more from IFRS. }\end{array}$ \\
\hline $\begin{array}{l}\text { Brüggemann, Daske, } \\
\text { Homburg, and Pope } \\
\text { (2012) [16] }\end{array}$ & $\begin{array}{l}\text { Examine the impact of global IFRS } \\
\text { adoption on cross-border equity } \\
\text { investment by individual investors. }\end{array}$ & $\begin{array}{l}\text { Sample of Open Market } \\
\text { Universe (Datastream } \\
\text { (DS) Universe) } 5637 \\
(22,280) \text { firms and } 43,671 \\
\text { (217,772) firm periods } \\
\text { from } 31 \text { countries for } \\
\text { period 2002-2008. }\end{array}$ & $\begin{array}{l}\text { - Stocks experience a significant increase in Open } \\
\text { Market trading volume following adoption of } \\
\text { IFRS. } \\
\text { - Global IFRS adoption enhances cross-border } \\
\text { equity investments by individual investors. } \\
\text { However, this effect does not materialize } \\
\text { equally across stocks due individual investors' } \\
\text { limited attention. } \\
\text { - Individual investors ignore the complex } \\
\text { interaction between IFRS adoption and the } \\
\text { institutional environment of the stocks, because } \\
\text { they tend to be less sophisticated than their } \\
\text { institutional peers and they predict that } \\
\text { individual investors focus on those stocks } \\
\text { within the IFRS-enhanced choice set that catch } \\
\text { their attention, for example, through increased } \\
\text { media coverage. }\end{array}$ \\
\hline $\begin{array}{l}\text { Chen, Ding and } \mathrm{Xu} \text {, } \\
\text { (2014) }[20]\end{array}$ & $\begin{array}{l}\text { Investigate if the convergence of } \\
\text { domestic and IFRS promotes FDI as it } \\
\text { reduces information processing costs } \\
\text { for foreign investors. } \\
\text { - Investigate also if the effect of reduced } \\
\text { information costs is stronger for } \\
\text { partner countries whose accounting } \\
\text { systems showed greater pre-convergence } \\
\text { differences because they magnify the } \\
\text { facilitating role of accounting standard } \\
\text { convergence for FDI. }\end{array}$ & $\begin{array}{l}\text { - Sample of bilateral FDI } \\
\text { data from } 30 \text { OECD } \\
\text { countries between } 2000 \\
\text { and } 2005 \text {. }\end{array}$ & $\begin{array}{l}\text { The convergence of domestic accounting } \\
\text { standards and IFRS promotes FDI as it reduces } \\
\text { information processing costs for foreign } \\
\text { investors. } \\
\text { - The effect of reduced information costs is } \\
\text { stronger for partner countries whose } \\
\text { accounting systems showed greater } \\
\text { pre-convergence differences because they } \\
\text { magnify the facilitating role of accounting } \\
\text { standard convergence for FDI. }\end{array}$ \\
\hline
\end{tabular}




\section{Continued}

Chen, $\mathrm{Ng}$, and Tsang • Examine whether mandatory IFRS (2015) [25]
De Fond, Hu, Hung, - Examine the effect of adopting a and $\mathrm{Li}$ (2011) [18]

Francis, Huang, Khurana, (2012) [17]
- Sample 37,384 frequency $\mathrm{M} \& \mathrm{~A}$ activities of 32 countries for period 1998 to 2004 with 643 country pairs, representing 32 acquirer and 32 target countries. adoption facilitates firms' cross-listing activities. uniform set of accounting standards like the mandatory IFRS adoption on comparability and cross-border investment.

- Examine the change in foreign mutual fund investment in firms that began using IFRS after its mandatory adoption in the European Union (EU) in 2005 .
- Sample of 8995 firms with 35,980 firm year observations from periods 2003-2004 and 2006-2007. Mandatory IFRS adopters are 1365 firms with 5460 year observations from 14 EU countries. Non IFRS adopters are 10 countries globally.
- Firms mandatory IFRS adopters exhibit significantly higher cross-listing propensity and intensity following IFRS adoption.

- Firms from mandatory IFRS adoption countries are more likely to cross-list their securities in countries also mandating IFRS and countries with larger and more liquid capital markets.

- IFRS adoption has a greater effect on mandatory IFRS adopters from countries with larger accounting differences from IFRS, lower disclosure requirements, and less access to external capital prior to IFRS adoption.

- Mandatory IFRS adoption facilitates firms' cross-listing activities and highlight the importance of considering the change in crosslistings when examining the capital market consequences of mandatory IFRS adoption.

- Mandatory IFRS adoption results in a greater increase in foreign investment among companies in countries with strong implementation credibility that experience relatively large increases in uniformity, and these firms show significantly increase in foreign mutual fund ownership.

- Improved comparability associated with mandatory IFRS adoption does not increase domestic mutual fund ownership, since domestic investors being more familiar with local accounting standards.

- The increase in foreign mutual fund ownership in response to improved comparability is primarily driven by foreign global mutual funds.

- The volume of M \& A activity across country pairs is larger for pairs of countries with similar Generally Accepted Accounting Principles (GAAP). markets.
Florou and Pope (2012) [12] Zhu (2012) [19]
- Examine whether the mandatory introduction of IFRS leads to an increase in institutional investor demand for equities.

Test the basic argument that the adoption of IFRS by a country results in increased foreign direct investment (FDI) inflows.
- Sample of 45 countries, 10,852 firms and 35,160 firm year observations from 2003 to 2006.

- Sample of 1343 observations covering 124 countries, for the period 1996 to 2009 .
- The takeover premium is higher if target countries' GAAP is similar to that of the acquiring firm's country.

- The 2005 mandatory adoption of IFRS increased cross-border M \& As among IFRS adopting countries, and that this increase is more pronounced for country pairs with low degree of similarity in GAAP in the pre-IFRS adoption period.

- Institutional holdings increase for mandatory IFRS adopters.

- Benefits from higher quality of financial statements, derived by IFRS, are evident on institutional holdings.

- Adoption of IFRS leads to increased FDI inflows.

- The overall increase in FDI inflows from IFRS adoption is due to the increase in FDI inflows by countries with developing economies.

- A key potential driver for IFRS adoption by countries with developing economies is the desire to receive financial aid from the World Bank. 


\section{Continued}

Hong, Hung, and Lobo (2014) [24]
- Examine the impact of mandatory IFRS adoption on IPO underpricing and the relative amount of IPO capital raised in foreign markets.
Khurana and Michas (2011) [22]

Lee and Fargher (2010) [21]

Louis and Urcan (2014) [15]
- Examine whether the adoption of IFRS is associated with an increase in the level of investment in foreign equities held by Australian investors.
Sample of 3651 IPOs worldwide, including 1540 firms in 20 mandatory IFRS adopters countries in 2005, and 2111 firms of 9 non IFRS adopters countries with sample periods of 2003-2004 and 2006-2007.

- Mandatory IFRS adoption decrease IPO underpricing and increase the relative proceeds from foreign markets.

- Mandatory IFRS adoption has a greater impact on IPO underpricing and relative foreign proceeds for firms in countries with a larger number of accounting changes, and this relation is more pronounced among firms in countries with stronger implementation credibility.

- The decrease in underpricing after mandatory IFRS adoption holds for both domestic IPOs and global IPOs, but this effect is more pronounced for global IPOs than for domestic IPOs.

- Sample of 85 countries, 33 that adopted IFRS during the 2003-2007 time period, 30 that continued to mandate local accounting standards through 2007, and 22 that mandated the use of IFRS even before 2003.
- A common set of global accounting standards matter for portfolio holdings of US investors and the enforcement of standards is a key factor in making investments outside the US

- US home bias decreases for countries that mandate IFRS adoption, after controlling for country-fixed effects.

- Mandatory IFRS adoption reduces the US home bias greater for countries with larger differences between IFRS and their domestic accounting standards, for countries with a stricter rule of law and a common law legal origin, and in countries with greater incentives to report high-quality financial information.
Sample 256 observations of 40 countries, including 21 IFRS-adopters and 19 non-adopters in 2002 to 2008.
- The adoption of IFRS is associated with greater cross-border equity investment.

- Investors benefited from a reduction in information asymmetry through an increase in the comparability of financial reports.
- Mandatory IFRS adoption substantially Sample of completed acquisitions 885 of listed firms from the adopting countries and 2285 acquisitions of unlisted companies from 2000 to 2010. increases cross-border acquisitions of listed companied in the adopting countries.

- IFRS adoption increase significantly the odds of a cross-border acquisition of a listed firm in the adopting countries.

- The increase in the flow of investment into the IFRS adopting countries comes from both non-IFRS adopting countries and other IFRS adopting countries.
Shima, and Gordon - Investigate whether a country's use of (2011) [23]
IFRS is associated with increased US investment in foreign equities.
- Sample of US holdings of - IFRS adoption is associated with US investment foreign equities for the years 2003-2006 in 44 countries. when it is combined with a strong regulatory environment, strong enforcement regime.

- Mandatory IFRS adoption is attractive to US investors only when combined with a strong regulatory environment. 
foreign investment, meaning greater cross-border investments and as a consequence a more efficient capital allocation (G. Lee and N. Fargher (2010) [21]). US investors are less home biased against investments in foreign countries that mandate IFRS adoption. This reduction in the US home bias following the mandatory IFRS adoption is greater for countries with significantly different local standards in the pre IFRS adoption period (I. K. Khurana and P. N. Michas (2011) [22]). There is a significantly positive association between a country's use of IFRS and increased US investment in foreign equities under a strong regulatory environment (K. M. Shima and E. A. Gordon (2011) [23]). There is a positive impact of mandatory IFRS adoption on IPO underpricing and capital source in global markets. This reduction in IPO underpricing is higher for firms in countries experiencing large accounting changes and are more evident among firms in countries with strong implementation credibility. Mandatory IFRS adoption reduces more underpricing for global IPOs than domestic IPOs, since foreign investors face greater information asymmetry than domestic investors, and thus benefit more from improved financial reporting $(\mathrm{H}$. A. Hong, M. Hung and G. J. Lobo (2014) [24]). Mandatory IFRS adoption has positive effects on firms' cross-listing activities but it also depends on the institutional characteristics in each country. However exogenous events which happen concurrently should be incorporated in the examination of the effects of IFRS adoption for better evaluation (L. Chen, J. Ng and A. Tsang (2015) [25]).

\section{Conclusions}

We presented existing literature on the effects of IFRS adoption on investment management, firstly under a European setting and more explicitly during the recent European crisis and secondly under a worldwide setting. Significant research efforts support that accounting harmonization in Europe is an important way to reduce the perceived risks so as to enhance international trade, foreign direct investments (FDIs), cross-border investments (Merger and Acquisition activities), and foreign mutual fund ownership. Productivity efficiency also seems to be improved after IFRS adoption. Of course, it has to be noticed that legal enforcement significantly contributes to the positive association between IFRS adoption on investment management.

Academic research results based on worldwide evidence, about the effects of IFRS adoption on investment management, identify a mitigation of investors' unfamiliarity of foreign markets and information asymmetry, which enhance foreign equity portfolio investments, cross border acquisitions, foreign mutual fund investment, domestic and global IPOs and thus improve investment efficiency.

Research limitations are not ignored by existing literature and could be summarized as differences in: characteristics of IFRS adoption and implementation process across countries; economies; regulations and capital markets development, thereby making it difficult to identify the causality effect and interpret the 
economic consequences of IFRS adoption. This means that additional academic research is required to explore more in depth the economic consequences of IFRS adoption across countries.

In terms of European crisis there are various conclusions but in general firms are trying to maintain their performance. Financial constraints are important during the crisis period to interpret the interaction of IFRS adoption and investment management.

IFRS adoption is considered to be positively associated with investment efficiency. Nevertheless, there is also a need for additional research effort so as to identify other parameters and indicators which could affect investment efficiency and apply concurrently within the continuous ongoing changes of the rapidly developing international financial reporting standards. Future research could incorporate macroeconomic factors, the implementation process of IFRS adoption among countries, the level of experience using IFRS, to better understand and evaluate the economic consequences of accounting harmonization. Additionally, different capital market conditions, regulations and institutional characteristics among IFRS adopting countries may be investigated having an impact on investment management.

\section{References}

[1] Marquez-Ramos, L. (2008) The Effect of IFRS Adoption on Trade and Foreign Direct Investments. International Trade and Finance Association Working Papers, Paper 19. http://services.bepress.com/cgi/viewcontent.cgi?article=1124\&context=itfa

[2] Schleicher, T., Tahoun, A. and Walker, M. (2010) IFRS Adoption in Europe and Investment-Cash Flow Sensitivity: Outsider versus Insider Economies. The International Journal of Accounting, 45, 143-168.

[3] Lenger, S., Ernsberger, J. and Stiebale, J. (2011) The Impact of IFRS on Firms' Investment Efficiency European Evidence on Private and Public Firms. The Illinois International Journal of Accounting Symposium, Porto Carras, Halkidiki, 23-25 June 2011.

http://business.illinois.edu/zimmerman/2011-illinois-international-journal-of-acco unting-symposium/

[4] André, P., Filip, A. and Marmousez, S. (2014) The Impact of IFRS on the Relationship between Conservatism and Investment Efficiency. Comptabilité Contrôle Audit, 20, 101-124. https://doi.org/10.3917/cca.203.0101

[5] Chen, C., Young, D. and Zhuang, Z. (2013) Externalities of Mandatory IFRS Adoption: Evidence from Cross-Border Spillover Effects of Financial Information on Investment Efficiency. The Accounting Review, 88, 881-914.

https://doi.org/10.2308/accr-50384

[6] Banker, R.D., Huang, R. and Li, Y. (2014) Do Accounting Standards Matter for Firm Productivity? Evidence from Mandatory IFRS Adoption. Working Paper. https://papers.ssrn.com/sol3/papers.cfm?abstract_id=2429121

[7] Márquez-Ramos, L. (2011) European Accounting Harmonization: Consequences of IFRS Adoption on Trade in Goods and Foreign Direct Investments. Emerging Markets Finance and Trade, 47, 42-57.

[8] Campello, M., Giambona, E., Graham, J.R. and Harvey, C.R. (2012) Access to Li- 
quidity and Corporate Investment in Europe during the Financial Crisis. Review of Finance, 16, 323-346.

[9] Boumediene, S.L., Nafti, O. and Boumediene, E. (2014) The Impact of IFRS Adoption during the 2008 Financial Crisis on the Relationship between Yield and Accounting Variables. Accounting \& Taxation, 6, 51-67.

[10] Balfoussia, H. and Gibson, H.D. (2016) Firm Investment and Financial Conditions in the Euro Area: Evidence from Firm-Level Data. Bank of Greece, Eurosystem, Working Papers, 208.

[11] Doukakis, L., Kapellas, K. and Siougle, G. (2017) The Effect of IFRS on Investment Decisions: European Evidence during Crisis and non Crisis Economic Conditions. SSRN Paper. https://papers.ssrn.com/sol3/papers.cfm?abstract_id=3020094

[12] Florou, A. and Pope, P.F. (2012) Mandatory IFRS Adoption and Institutional Investment Decisions. The Accounting Review, 87, 1993-2025. https://doi.org/10.2308/accr-50225

[13] Amiram, D. (2012) Financial Information Globalization and Foreign Investment Decisions. Journal of International Accounting Research, 11, 57-81.

https://doi.org/10.2308/jiar-50282

[14] Biddle, G.C., Callahan, C.M., Hong, H.A. and Knowles, R.L. (2015) Do Adoptions of International Financial Reporting Standards Enhance Capital Investment Efficiency? Working Paper.

https://papers.ssrn.com/sol3/papers.cfm?abstract_id=2353693

[15] Louis, H. and Urcan, O. (2014) The Effect of IFRS on Cross-Border Acquisitions. Working Paper. https://papers.ssrn.com/sol3/papers.cfm?abstract_id=2164995

[16] Brüggemann, U., Daske, H., Homburg, C. and Pope, P.F. (2012) How do Individual Investors React to Global IFRS Adoption? Working Paper, August 1, 2012, AAA 2010 Financial Accounting and Reporting Section (FARS) Paper. https://papers.ssrn.com/sol3/papers.cfm?abstract_id=1458944

[17] Francis, J.R., Huang, S.X. and Khurana, I.K. (2012) The Role of International GAAP in Cross-Border Mergers and Acquisitions. Working Paper, September 17, 2012. https://papers.ssrn.com/sol3/papers.cfm?abstract_id=2131472

[18] DeFond, M., Hu, X., Hung, M. and Li, S. (2011) The Impact of Mandatory IFRS Adoption on Foreign Mutual Fund Ownership: The Role of Comparability. Journal of Accounting and Economics, 51, 240-258. https://doi.org/10.1016/j.jacceco.2011.02.001

[19] Gordon L.A., Loeb M.P. and Zhu, W. (2012) The Impact of IFRS Adoption on Foreign Direct Investment. Journal of Accounting and Public Policy, 31, 374-398. https://doi.org/10.1016/j.jaccpubpol.2012.06.001

[20] Chen, C.P., Ding, Y. and Xu, B. (2014) Convergence of Accounting Standards and Foreign Direct Investment. The International Journal of Accounting, 49, 53-86. https://doi.org/10.1016/j.intacc.2014.01.007

[21] Lee, G. and Fargher, N. (2010) Did the Adoption of IFRS Encourage Cross-Border Investment? Working Paper. https://papers.ssrn.com/sol3/papers.cfm?abstract_id=1686571

[22] Khurana, I.K. and Michas, P.N. (2011) Mandatory IFRS Adoption and the U.S. Home Bias. Accounting Horizons, 25, 729-753. https://doi.org/10.2308/acch-50075

[23] Shima, K.M. and Gordon, E.A. (2011) IFRS and the Regulatory Environment: The Case of U.S. Investor Allocation Choice. Journal of Accounting and Public Policy, 
30, 481-500. https://doi.org/10.1016/j.jaccpubpol.2011.07.001

[24] Hong, H.A., Hung, M. and Lobo, G.J. (2014) The Impact of Mandatory IFRS Adoption on IPOs in Global Capital Markets. The Accounting Review, 89, 1365-1397. https://doi.org/10.2308/accr-50720

[25] Chen, L., Ng, J. and Tsang, A. (2015) The Effect of Mandatory IFRS Adoption on International Cross-Listings. The Accounting Review, 90, 1395-1435.

https://doi.org/10.2308/accr-50982 